\title{
Reflexão
}

\section{sobre uma viagem sem fim}

MILTON HATOUM

Para BENEDITO NUNES
Quando vi Felix Delatour pela primeira vez, à porta de um pequeno sobrado neoclássico no centro de Manaus, não sabia que aquele encontro seria para mim uma grande descoberta: viagem inicial em torno de um texto cuja leitura me parece até hoje enigmática.

Para comentar esse encontro com Delatour, devo dar uma volta pela minha infância em Manaus, e recordar a voz de Yasmine, a matriarca da casa. Eu escutava Yasmine cantar e rezar, não em árabe, sua língua materna, mas em francês, sua língua adotada. De vez em quando a voz de Yasmine era abafada por uma outra mais grave, mais incisiva, a do almuadem: voz do muçulmano da família que falava mais alto, como se quisesse neutralizar a presença do colonizador francês em plena Amazônia. Mas a voz de Yasmine, o som mais que o sentido, parecia-me mais convincente: nas noites de insônia da infância ela latejava na minha memória, e eu repetia mentalmente uma palavra ou um pedaço de frase, como um infante que, encantado com uma reza ou um canto, se entrega a uma aprendizagem litúrgica, a um culto privado de que só nós dois participávamos.

Não era apenas a voz de Yasmine que contrariava o patriarca da casa: ela (Yasmine) cultivava amizades estranhas: estrangeiros do Ocidente que tinham uma expressão esnobe de cidadãos do mundo, gentes que viviam à margem da sociedade provinciana e freqüentavam os salóes de festa dos transatlânticos que atracavam no Manaos Harbour e bebiam e dançavam como se estivessem em algum hotel particular perto da ponte Alexandre III. Mas entre esses amigos esquisitos havia um ou dois que ela citava com freqüência. Ontem conversei com o senhor Verne. Ele é muito imaginoso, tem o jeito de um dândi e já morou em Dakar, Caiena e Macau antes de aportar em Manaus, me dizia Yasmine. O senhor Verne falava vários idiomas e era um estudioso das línguas indígenas. Em Manaus, ele se empenhava na execução de um curioso trabalho filantrópico que consistia no que ele chamava de anticatequese: insuflar (discretamente) os índios contra os padres e patrões e promover a cultura indígena. Para tanto, ele fundou uma certa "Sociedade Montesquieu", de duração efêmera, cuja finalidade era " educar para libertar". Yasmine comentava também as proezas de Felix Delatour: Um bretão circunspecto, quase albino, e que sofre de uma enfermidade rara: o gigantismo. Não é fácil falar com ele, porque vive trancado numa sala e não recebe alma viva, informou Yasmine.

Os conhecidos esnobes de Yasmine nunca me interessaram; na verdade, eram seres invisíveis, ou melhor, era possível encontrá-los nos clubes ingleses da cidade ou a bordo do Cyril e do Hildebrand. Mas esses dois, Delatour e o senhor Verne, me aguçaram a curiosidade.

Numa manhã de chuva torrencial, uma dessas manhãs manauaras que parecem infindáveis, Yasmine me disse: Já que pretendes estudar francês, deves visitar o Monsieur Delatour amanhã mesmo, de tardinha.

Depois, com um sorriso enigmático, completou: É o francês mais excêntrico do Amazonas.
MILTON HATOUM É professor de Literatura Francesa da Universidade do Amazonas e autor do romance Relato de um Certo Oriente (Companhia das Letras). 
Anos mais tarde, descobri que a palavra excêntrico era a mais exata para evocálo. No primeiro contato ele foi lacônico. Aconteceu no entardecer de um dia de julho de 1959: o adolescente tímido e franzino dirige-se a uma pessoa idosa e diz com uma voz trêmula: Yasmine me disse que Monsieur Delatour leciona francês...

Apenas pude ver um pedaço do seu rosto na porta entreaberta. Ele me olhou por um momento, depois uma voz rouca disse: Amanhã de manhã, antes das sete.

Ao retornar na manhã do dia seguinte, notei que a porta estava aberta; pouca coisa pude observar na sala sombria do sobrado em que ele morava. Aquela sala era um espaço misterioso que ele sempre evitava freqüentar. Desde o primeiro dia, e assim durante seis ou sete meses, só conheci o andar superior do sobrado: uma sala avarandada, de onde se podia contemplar um horizonte de águas escuras interrompido por uma paisagem de palafitas. Na sala havia apenas uma mesa de madeira e duas cadeiras de vime. Quatro livros abertos e quatro lápis vermelhos estavam dispostos sobre a mesa. Um mapa-múndi fixado na parede era a única imagem de um espaço que hoje ressurge na minha memória como uma câmera de luz intensa.

Nos dias e meses que se seguiram, Delatour falou sobre a língua francesa, e quando lhe fazia uma pergunta sobre um item gramatical ou um exercício da escola, ele fazia uma expressão de enfado e desviava a conversa. O que lhe interessava eram as viagens, as muitas viagens que fizera durante a vida. Ele deixara a Bretanha há muitos anos para morar no outro lado da Terra. Seu desejo era descobrir o Amazonas, partir, sempre em busca do desconhecido. Como alguém que tem sede de espaço ou um botânico que passa a vida na floresta pesquisando pólens e tecidos vegetais, pensei.

Um dia perguntei se ele conhecia o dialeto bretão ou uma das tantas línguas indígenas do Amazonas. Vi o seu rosto branco e um pouco rechonchudo ruborizar (um rosto sem rugas, com uma barba rala e esbranquiçada, e os olhos azulados que ao fitar uma pessoa durante uma conversa pareciam expressar uma dúvida ou indagação), e subitamente ele se levantou, foi até a varanda, e, de costas para o rio, disse: Yasmine me confundiu com Armand Verne. Ele, sim, é um lingüista aplicado e tutor dos nativos. Verne pensa que pode promover a cultura indígena elaborando cartilhas bilíngües. Monsieur Verne comete um equívoco: não se pode dominar totalmente um idioma estrangeiro porque não podemos ser totalmente Outro. Um pequeno deslize no acento ou na entonação já assinala uma distância entre os dois idiomas, e essa distância é fundamental para mantermos o mistério da língua nativa, prosseguiu Delatour, sem esconder na fala um forte sotaque que reiterava a sua afirmação. Minha timidez não me impediu de lhe fazer outras perguntas: Por que tinha vindo ao Amazonas? Por que morar em Manaus, essa cidade ilhada e talvez perdida?

Ele olhou para o mapa-múndi, apontou para uma região da França: Ali reside uma infância, disse.

Ali, onde? perguntei.

No Finistere, num vilarejo ilhado e talvez perdido. Alguém, um viajante que andou pela Amazônia, me deu de presente o mapa desta região. E os mapas, como tu sabes, fascinam as crianças, são desenhos misteriosos que as convidam a fazer viagens imaginárias. Os périplos da minha infância, irreais como os sonhos, começaram nos limites do quarto fechado, à espera do sono, não longe do mar e das falésias abruptas da Bretanha.

Por um certo tempo não tocamos nesse assunto. Às vezes, nada falávamos: na sala branca, iluminada pelo sol da manhã, escutávamos o ruído dos barcos, monótono, insuportável. Enquanto eu pensava em alguma pergunta ou dúvida, ele lia um livro e fazia anotações com um lápis vermelho. Nem o rumor de um motor nem o calor matinal o incomodavam. Tinha diante de mim um leitor que parecia dialogar com o texto, ou seja, um verdadeiro leitor, e isso, para mim, era uma novidade, uma descoberta.

Numa dessas manhãs em que não conversávamos, alguém bateu à porta. Delatour desceu para ver quem era, e depois escutei a voz de uma mulher. Passei a folhear um dos livros abertos, mas antes tive o cuidado de memorizar a página que ele estava lendo. A voz da mulher no interior da casa me deixou curioso, e quando Delatour voltou à sala, eu fiz menção de partir. Não é uma visita convencional, disse ele. Conheces a índia Leonila? Ela passa por aqui uma vez ao mês. Pede para entrar, observa os livros da biblioteca, cochila um pouco na rede do meu quarto e vai embora sem me avisar. Ela anda descalça, veste sempre a mesma roupa, pode ser con- 


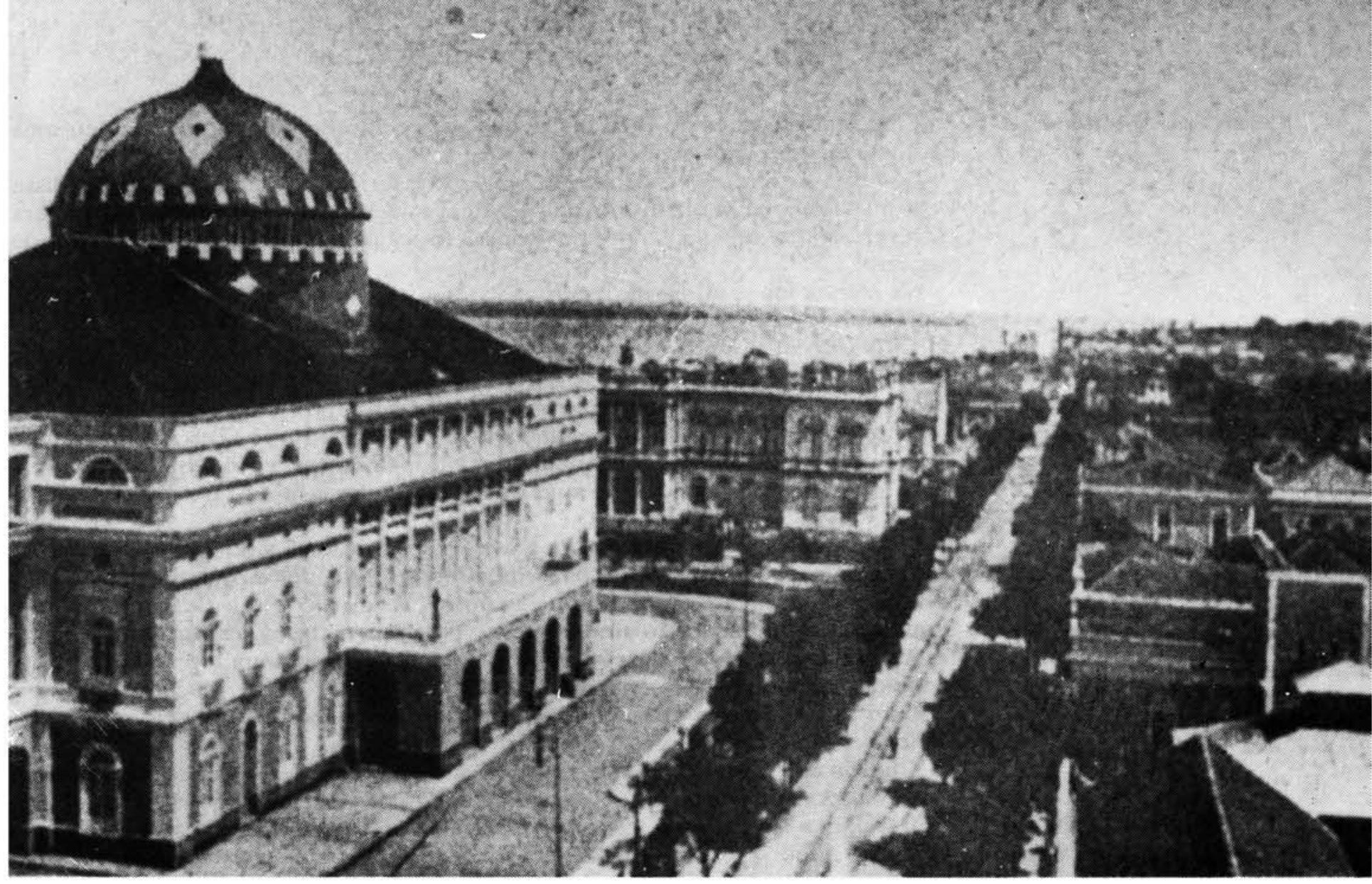

fundida com um mendigo qualquer. Mas é uma mulher que conhece a história de Manaus e seu histórico teatro sua tribo. Certa vez, sem que eu the pedisse, ela começou a falar sobre isso: a história, a violência, os mitos... Verne também aprendeu muito com ela, mas Verne insiste em querer falar por ela.

Alguma coisa havia entre Felix Delatour e Armand Verne, mas não quis abelhudar. Yasmine nada me contou a esse respeito, apenas disse: Verne viaja no espaço, Delatour no tempo.

$\mathrm{Na}$ manhã da visita de Leonila, ele notou que eu estava folheando um livro, e então passou a ler em voz alta poemas de Verlaine. Depois pedia para que eu os recitasse sem imitar seu sotaque.

Não consigo entender muita coisa - disse-lhe com um pouco de apreensão.

Por enquanto, isso é o de menos - afirmou. - O que importa, agora, é encontrar uma outra voz de Verlaine ou apenas captar o ritmo e a melodia de cada verso. Virou o rosto para a varanda. Disse: Numa primeira mirada a floresta é uma linha escura, não se consegue assimilar muita coisa. Mas no meio da escuridão há um mundo em movimento, milhões de seres expostos à luz e à sombra .

Depois Delatour citou como exemplo o mapa da Amazônia que o fascinara na adolescência. Para ele, a floresta era um mundo quase inverossímil, e por isso mesmo fascinante. Ele chegou a construir uma floresta em miniatura, estriada por uma teia de rios, afluentes e braços de afluentes cujos nomes de origem indígena ele afirmava pronunciar como um bárbaro.

A imaginação se nutre de coisas distantes no espaço e no tempo - afirmou, como se falasse para si mesmo.

Ele fez esse comentário pouco tempo antes de eu partir de Manaus. Quando soube que eu pretendia viajar para o sul do Brasil, ele ficou entusiasmado e falou certas coisas que eu nunca esqueci.

A viagem - disse Delatour - , além de tornar o ser humano mais silencioso, depura o seu olhar. A voz do verdadeiro viajante ecoa no rio silencioso do tempo.

Ao ouvir essa sentença do meu professor, percebi que as grandes viagens que ele mencionara não se referiam a uma vida rastreada de aventuras, como a do viajante seduzido por um mistério intransponível, e sim da aventura do conhecimento, como alguém que viaja para aprender, e aprende para lembrar. 
de um personagem que abandona um país europeu para morar numa região equatorial. Com o passar do tempo, esse personagem assimila algo do Outro, e percebe, com uma certa apreensão, que o estigma de sua condição de estrangeiro já é menos visível: algo no seu gesto ou na sua voz se turvou, perdeu um pouco do relevo original. Nesse momento, as origens do estrangeiro sofrem um abalo. A viagem permite a convivência com o outro, e aí reside a confusão, fusão de origens, perda de alguma coisa, surgimento de um outro olhar. Viajar, pergunta o personagem de Delatour, não é expor-se ao ritual do canibalismo? Todo viajante, mesmo o bemintencionado ou que se pretende neutro, corre o risco de julgar o Outro: consciente ou não, intencional ou superficial, este julgamente quase sempre deforma o rosto alheio, onde se projetam os horrores e as taras de quem observa.

A viagem mais fecunda, diz o personagem, é a que desvela a face dissimulada e obscura do porto de origem: é essa paisagem familiar que abriga a nossa discórdia com o mundo. O prazer da viagem é efêmero porque permeado por um sentimento de perda: a sensação de liberdade na terra estranha é a revelação de algo que nos falta, algo que procuramos no porto do passado. Talvez por isso o personagem de Delatour viaja para descobrir a si mesmo. Esta descoberta, que é também busca e extravio, não exclui a imagem que o narrador-viajante constrói do Outro: imagem fugidia ou esfumada, mas de alguma forma presente na visão de quem navega em águas estranhas.

O viajante, no convívio com o Outro, passa a privilegiar o olhar, pois é no silêncio do olhar que tudo acontece: o desejo de possuir e ser possuído, a entrega e a rejeição, o temor de se perder no Outro. O silêncio do olhar fabrica uma imagem que a memória, ao longo do tempo, pode evocar, perder, reinventar.

De onde parte o personagem - viajante de Delatour? De Cancale, na Bretanha: " um porto tão estranho que ninguém ou quase ninguém é capaz de deixá-lo". Em Cancale começa a travessia do Atlântico, uma travessia tempestuosa que termina num porto também estranho do hemisfério sul: um lugar sem nome, ilhado, habitado por pessoas que parecem resignadas ao confinamento e à clausura.

$\mathrm{Na}$ passagem mais enigmática do texto de Delatour o narrador, ao evocar esse porto, acaba inventando uma linguagem. O ritmo da frase se altera bruscamente e a voz do personagem torna-se uma confusão de neologismos e injúrias que beiram a bestialidade: a voz do narrador-viajante lembra a de um louco vociferando em várias línguas (2). São apenas doze linhas que destoam desse manifesto poético, como uma breve festa de sons: um ruído no meio de uma noite serena. Por causa desse trecho, renunciei à tradução dessa Viagem sem Fim.

Quase vinte anos passaram entre o primeiro encontro com Delatour e o meu regresso a Manaus. Eu o procurei por toda a cidade, em vão. Yasmine, com uma voz fraca que parece um sopro, me diz que em janeiro de 1978 ele enveredou rio acima, até alcançar o Cassiquiare, que liga a bacia do Orenoco à do Amazonas. Nenhuma pista sobre seu destino obtive no consulado da França em Manaus. O sobrado em que ele morava, numa das alamedas que desembocam no rio Negro, encontra-se abandonado. Creio que em poucos meses será um sobrado em ruínas: raízes de apuizeiro destroem a estátua de uma Diana e ameaçam uma parede que um dia já foi branca. Na parte térrea, crianças imundas e miseráveis cheiram cola, e com pedaços de carvão traçam garatujas na mureta que contorna o pátio. Um cheiro de podridão e excremento exala do interior da casa.

No verde desbotado da fachada leio uma frase curiosa, escrita a cal: A natureza ri da cultura.

Agora já amanhece: posso ver crianças amontoadas, dormindo no piso do pátio, solidárias e tristes no chão úmido da casa abandonada.

Ao divisar a varanda que dá para o leste, posso também imaginar Delatour contemplando o horizonte aquático no amanhecer neblinoso, como alguém que se deixa levar pela lenta correnteza de um rio.

Ali, o tempo flui como a imagem de um sonho: flui no pouco da noite que resta e no instante de luz que anuncia a manhã.

Antes de me afastar do sobrado, percebo que uma das crianças que rabiscava na mureta do pátio me olha com apreensão. Calada, imóvel, com o pedaço de carvão na mão direita, ela parece surgir desse crepúsculo da madrugada. De soslaio, a criança me olha ou finge olhar para mim. Este olhar me paralisa e causa espanto. E, à semelhança do texto de Delatour, parece afirmar algo assim: somos alguma coisa essencialmente misteriosa, como aquele mapa que nos fascinou na infância.
2 Nessa passagem do texto de Delatour, a lingüista Odile Lescure. pesquisadora da ORSTOM, encontrou referências dialetais usadas por índios e caboclos do Amazonas. $\mathrm{Na}$ verdade, são "transcriaçöes" de palavras e expressōes das línguas nheengatu e baniwa faladas nos rios Negro e Içana 